\title{
ISLAMIC PRINCIPLES ON KHITBAH AND COURTSHIP VERSUS THE EFFECTS OF SOCIAL MEDIA ON MUSLIM MARRIAGES IN NORTHERN NIGERIA
}

\author{
Aliyu Alhaji Rabiu ${ }^{1}$ \\ Dahiru Inuwa Ibrahim ${ }^{2}$ \\ Jaafar Sa' $\mathbf{a d}^{3}$
}

\begin{abstract}
Khitbah and Courtship are part of the foundational stages for the formation of a matrimonial home which largely depend on the moral climate of a given society at a particular time. It is a volatile stage in which people make or mar their matrimonial lives. As marriage proposal and steps taken by prospective couples to understand one another better, are practices approved by the Shariah with prescribed ethical principles. However, these noble acts are observed to be bastardized by modern young prospective Muslim couples in northern Nigeria which in the short or longrun affect the socio-moral standing of the matrimonial home and in some ways, even the children to be born as well as the larger
\end{abstract}

1 Lecturer, Department of Religious Studies, Faculty of Arts and Social Sciences, Gombe State University, Nigeria, aliyurabiu39@gmail.com; arabiu002@gsu.edu. ng

2 Senior Lecturer, Department of Religious Studies, Faculty of Arts and Social Sciences, Gombe State University, Nigeria, abusumayya74@gmail.com

3 Graduate Assistant, Department of Religious Studies, Faculty of Arts and Social Sciences, Gombe State University, Nigeria, jaafarsaad10@gmail.com 
society. Perceptibly, gross abuse of the social media platforms and blind imitation of some ill-western traits in courtship coupled with unnecessarily longer courtship period are the identifiable factors that challenge the Shariah-based rule of courtship behavior in contemporary times. Therefore, the paper discussed Shariah provisions on khitbah and courtship while highlighting how some potential Muslim couples in Northern Nigeria are deviating from this guidance which ultimately affect the family institution as a social fabric of the society. Considering the theoretical and empirical nature of this study, both qualitative and quantitative methodologies were used in data collection, analysis and presentation. The results of the research showed that there are abuses and malpractices in khitbah and courting behavior by to be couples and their families which adversely affect the moral standing of matrimonial homes and the larger society. It is recommended that, Muslim youth and their parent should adhere strictly to the Shariah rules on khitbah and courtship and formal pre-marital counseling centers should be established by Masajid and Muslim organizations to help address the situation.

Keywords: khitbah, courtship, social media, Muslim youth, morality and globalization

\section{INTRODUCTION}

Islam as a comprehensive way of life, has provided guidance for every aspect of human life to help mankind fulfill the purpose of his existence on earth, i.e. the worship of the Only Allah where He says:

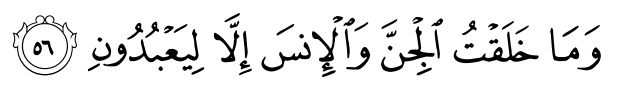

"And I (Allāh) created not the jinns and humans except they should worship Me (Alone)."

(Surah al-Dhāriyāt, 51: 56)

Shariah as a set of divine codes that regulate all facets of every Muslim's life leaves no stone unturned in the conduct of marriage as a socio-spiritual institution. Because of the nobility and sacrosanctity of the marriage institution, many of the esteemed Prophets of Allah (SWT) entered into it as confirmed in the following verse:

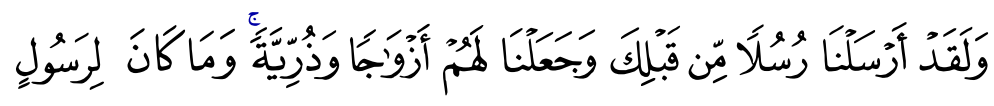


Islamic Principles on Khitbah and Courtship Versus the Effects of Social Media on Muslim Marriages in Northern Nigeria

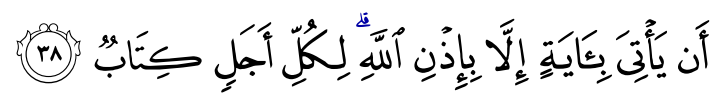

"And indeed We sent Messengers before you (O Muhammad $S A W)$, and made for them wives and offspring. And it was not for a Messenger to bring a sign except by Allāh's Leave. (For) each and every matter there is a Decree (from Allāh)."

(Surah al-Ra'd, 13: 38)

The last of the Prophets, Muhammad (SAW), whom the Muslims were ordered to emulate and obey his commands has epitomized all the how(s) and what(s) of marriage. Based on his Sunnah, Islam laid down principles to guide all pre-marital, matrimonial and post-marital practices and sacraments. These include the etiquettes and ethos of marriage proposal (khitbah), marriage contract ( 'aqd al-nikāh), matrimonial life (al- 'ishrah), house maintenance (alnafaqah), divorce (al-talāq), children-upbringing and custody (al-haḍānah), inheritance (al-mīrāth) and other overlapping rights and obligations of the various family units. Courtship, is one of the focal elements of the preliminaries of marriage which in most cases is preceded by khitbah (betrothal). It is an interplay that gives a prospective couple, the chance to know and understand one another better for the purpose of establishing a match-able marriage union based on certain approved practices and modest standards.

The foundation for a morally upright family is built first by identifying and choosing the right partner- "the better half" for oneself based on the criteria set down by Prophet Muhammad (SAW) for both males and females who intend to marry. This is followed by courting decently and contracting the marriage according to the requisites and etiquettes of the Shariah. A conglomeration of this type of families produces a model of morally upright society enveloped by peace, social cohesion and economic prosperity. This trend has been the case of most families since the first century of Islam and the same nobility has characterized many traditional Muslim families in Nigeria as well. However, with the dawn of modernity amidst globalization and to a certain degree immodest westernization that permeated the fabrics of Muslim societies; things begin to fall apart. In the recent past, with the invention of mobile phones and internet services together with enabling social networking platforms, the world became in more practical means a global village. Due to this booming development, no amount of distance is considered a barrier between individuals, societies and even governments at various tiers when it comes to communication.

Conversations and conducts in courting among intending couples are identified as part of the social traits that are influenced by globalization and 
its agents across Muslim societies in Nigeria. Though, positive in some ways, but the negative effects are glaringly overwhelming. Through both print and electronic media, in form of novels, movies, online videos which are freely watchable and downloadable on YouTube, young prospective Muslim couples become lured to indecent relationships and practices facilitated by what could be termed as "social media courtship." This research therefore presents the normative provisions of the Shariah on khitbah and courtship as well as investigates how devastating neglecting them is to the couples concerned and ultimately the society.

The paper explained how Shariah-compliant conduct of courtship could be achieved based on the Quranic and Prophetic guidance. It appraises how courtship is conducted in the $21^{\text {st }}$ century world mostly by young intending Muslim couples across some States in Nigeria against the Islamic and in some instances even cultural standards of courting. Finally, some propositions were made to help address or manage the challenges posed by modernity to the noble institution of marriage among Muslims.

\section{OPERATIONAL DEFINITION OF TERMS}

For the sake of clarity and domestication of terminologies used in this paper, the following key words are elucidated:

\section{Social Media}

The word media in this compound term signifies a means of communication. Social media therefore, denotes a social instrument of communication, though, with no single recognized definition as argued by Jacka and Scott. ${ }^{4}$ However, the Oxford Dictionary defines social media as 'websites and applications used for social networking'. In turn, social networking is defined as 'the use of dedicated websites and applications to communicate with other users, or to find people with similar interests to one's own. Examples of popular social networking sites include Facebook, Twitter, Instagram, and WhatsApp, with the latter gaining patronage more than the rest having not less than 1.5 billion active users (mostly aged between 16 and 40) globally as at of $2018 .{ }^{5}$ Emphasis in this research is placed on the most frequently used social platforms such as

\footnotetext{
$4 \quad$ Peter R. Scott \& J. Mike Jacka, Auditing Social Media: A Governance and Risk Guide (New Jersey: John Wiley \& Sons, Inc. 2011), 5.

5 Craig Smith, '65 Amazing WhatsApp Statistics and Facts.' DRM, https:// expandedramblings.com/index.php/whatsapp-statistics/, assessed on 24 January 2018.
} 
WhatsApp and Facebook due to their user-friendliness and instant messaging ability.

\section{Khitbah}

Khitbah is derived from the Arabic verb khațaba, yakhtubu, khitbatan, meaning when a man seeks a lady's hand in marriage. ${ }^{6}$ By this, there is no clear difference between the literal and technical definitions of khitbah. Sham defines it technically; as a promise of a man with the intention that he will marry a certain woman. It is a sort of agreement that serves as a preliminary to the contract of marriage. ${ }^{7}$ While Bello, understands khitbah as the formal permission sought by a suitor from the parent or guardian of the lady in question. ${ }^{8}$ The word khitbah is mentioned in the Glorious al-Qur'ān, as Allah (SWT) says:

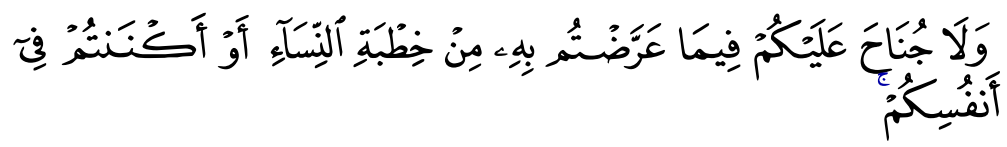

"And there is no sin on you if you make a hint of betrothal (khitbah) to women or conceal it in yourselves."

(Surah al-Baqarah, 2: 235)

\section{Courtship}

Courtship is described by the Oxford Advanced Learners'Dictionary as an art or process of developing a close relationship with a person of the opposite sex with the idea/intent of marrying. Imam, defines courtship as a union between prospective Muslim male and female couple determined to end the

6 S. Sābiq, Fiqh al- Sunnah, vol. 2 (Bayrūt: Dār al-Kutub al-'Arabī, 1977), 24; T. AbdulKariem, 'Administration of Islamic Law of Marriage and Divorce in South Africa,' (Master Dissertation, Department of Islamic Studies, Faculty of Arts, University of Durban-Westville, 1993), 73.

7 S. Iqbal Shahzad, Some Aspects of Marriage and Divorce in Muslim Family Law (n.p.: n.p., n.d.), 13.

8 I. Bello (Senior Researcher, Da'wah Institute of Nigeria (DIN), Islamic Education Trust (IET), Minna, Niger State), in interview with author via online on 12 December 2017. 
relationship in nikāh devoid of any act of immoralities, ${ }^{9}$ where Giwa, sees it as the period between acceptance of marriage proposal (khitbah) and the solemnization of marriage; ${ }^{10}$ whereas, Lemu considers courtship as all the (halal) activities that a prospective couple are engaged in that assist them in deciding on whether or not to get married. ${ }^{11}$ While trying to understand one another, the prospective couple may engage in some approved gestures and practices such as exchanging gifts, pleasantries and sharing letters or words of love within the confines of the Shariah. Therefore, this is different from dating which is romantic in nature and involves intimate relationship by the parties involved. The act of courting, in many instances is heralded by khitbah.

\section{Modernity}

Is a quality of being modern. As a phenomenon of historical periodization, it depicts ensemble of a certain socio-cultural norms, attitudes and practices that prevail in the post-medieval era. ${ }^{12}$ As a period therefore, modernity, is characterized by contemporariness, currency, industrialization, globalization and technological advancement. Hence, the term modern as used in this paper, refers specifically, to the $21^{\text {st }}$ century globalized contemporary world-the digital age.

\section{Morality}

This is an ethical standard that represents the differentiation of intentions, decisions and actions between those that are good (or right) and those that are bad (or wrong). The term morality according to Business Dictionary, means, conformance to a recognized code, doctrine, or system of rules of what is right or wrong and to behave accordingly. Simply put, morality refers to discipline of mind, actions, dispositions, attitudes, virtues, and the ways of life that should be found in a good person. ${ }^{13}$ It is also referred to an innate disposition,

$9 \quad$ Y.O Imam (56) (Professor, Islamic Studies, University of Ilorin, Kwara State, Nigeria), in interview with author via online on 3 December 2017.

10 A.O. Giwa (Masjid Imam, Ogun State), in interview with author via online on 6 December 2017.

11 M.N Lemu (Director, Research and Training Department, Da'wah Institute of Nigeria (DIN), Islamic Education Trust (IET), Minna, Niger State), in interview with author via online on 6 December 2017.

12 Wikipedia, 'Modernity,' https://en.wikipedia.org/wiki/Modernity, accessed on 18 December 2017.

13 P.K. Olawale, 'The Moral Teachings of Suratu Luqman as Paradigms for Character,' NATAIS Journal, vol. 6/2 (2002): 14. 
character, ethics, demeanor, conduct and behavior of a person in a given society. ${ }^{14}$ Therefore, the moral standing referred to in this paper, encompasses the presence of these moral traits; decency, honesty, integrity, trustworthiness, respect etc. in the course of courtship and in the matrimonial home of the target group under examination.

\section{Youth}

This is a term that has no unanimous definition due to varying yardsticks used by different individuals, groups and institutions to determine its meaning. Some use age brackets to determine the youthful age while others consider qualities that make up a youth. In the Nigerian context, the National Youth Policy views youth as "Young persons of ages between 18 and 35." 15 However, in many other countries, youthful age, is generally fixed within 14 and 24 age-brackets. ${ }^{16}$ Observably, as rightly opined by Abubakar ${ }^{17}$ and Rabiu, ${ }^{18}$ some inherent inequalities exist in age-bracket definitions of youth; mainly of inclusion and exclusion of certain personalities who by virtue of either psychological or physiological composition are or not counted as youth. Therefore, this paper considers youth as persons who fall between childhood and adulthood stage of human development which is often described as the period of physical and psychological strength from onset of puberty and early adulthood; persons of this caliber are found within the age-range of 15 to 40 years. This is the period that al-Qur'ān describes as a stage between two weaknesses thus:

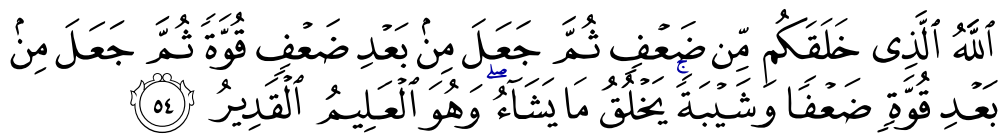

14 Z. I. Oseni, 'Islam and Morality,' Nigeria Studies in Religious Tolerance, vol. 2/26 (1988): 7.

15 N.a., 'Nigeria's Public Policy and the Youth,' http://www.thetidenewsonline.com, accessed on 6 July 2014.

16 O. Oloyede, 'An Islamic Perspective of Youth Development,' in African Culture, Modern Science and Religious Thought, ed. P. A. Dopamu (Ilorin: African Centre for Religions and the Sciences, University of Ilorin, 2003), 664.

17 A.L. Abubakar, 'Youth Unemployment, Poverty and Political Violence in Nigeria,' in the Proceeding of the Conference on: Youth Unemployment, Poverty and Political Violence in Nigeria (Gombe: Department of Sociology, Gombe State University, 2012).

18 A.A. Rabiu, 'Effects of Electronic Media on the Muslim Youth of Gombe Metropolis,' Journal of Religion and Culture, UniPort. vol. 17/1 (2017): 62. 
"Alläh is He Who created you in (a state of) weakness, then gave you strength after weakness, then after strength gave (you) weakness and grey hair. He creates what He wills. And it is He Who is the AllKnowing, the All Powerful (i.e. Able to do all things)."

(Surah al-Rūm, 30: 54)

In the Qur'anic worldview also, the height of man's youthful age is placed at 40 years as in the following verse:

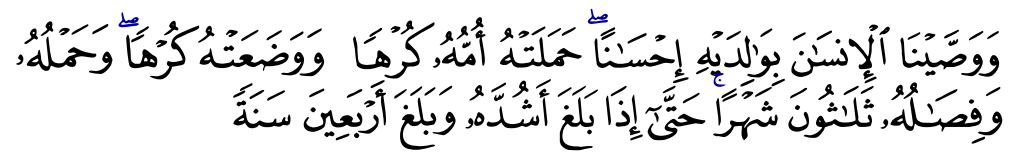

"And We have enjoined on man to be dutiful and kind to his parents. His mother bears him with hardship and she brings him forth with hardship, and the bearing of him, and the weaning of him is thirty months, till when he attains full strength and reaches forty years."

(Surah al-Aḥqāf, 46: 15)

\section{METHODOLOGY OF THE STUDY}

Considering the nature of this research being both empirical and theoretical, the duo-methodologies of qualitative and quantitative approaches were applied in data collection, where Stata 14 software was used for analysis and presentation of the data obtained from the questionnaire. Written and oral structured interviews were conducted alongside questionnaires designed on google form and administered in both print as well as online media to different target groups via which valuable information was retrieved from the respondents on the subject matter. The target groups to whom questionnaires were given included the Youth, both singles and newlywed. Parents, both fathers and mothers and Islamic scholars selected from different parts of Nigeria were interviewed. The study applied such descriptive techniques as bar chart, column and pie-chart, in the data analysis.

The population for this research is the population of Northern Nigerian Muslims within the age bracket of 15-40. However, there is no official statistical data on this target population. As a result, the study drew a moderate sample size of 241 using convenient sampling technique. Therefore, the researchers used the available network of friends and colleagues to reach out to most of the respondents who are digitally-oriented via administering a Google-based questionnaire. 
Quantitative method, especially binary Probit regression model, was used to estimate the major causes of disapproved courtship practices and its impacts on the society. This model was chosen because the dependent variables are discrete or binary dummies where courtship practices were coded one if they are Islamically disapproved and otherwise zero. The effects of the courtship practices were also coded one if they are negative and otherwise zero. The model of factors causing disapproved courtship practices could be specified in econometric form as in equation (1):

$\log \left[\frac{\operatorname{Pr}(\text { disapprovedcourship }}{1-\operatorname{Pr}(\text { disapprovedcourship }}\right]_{i}=\beta_{0}+\beta_{n}$ Factors $_{i}+\mu_{i}$

Where $\operatorname{Pr}$ (disapprovedcourtship) is the probability of engaging in disapproved courtship practices; 1 - $\operatorname{Pr}$ (disapprovedcourtship) is the probability of not engaging in disapproved courtship practices; and Factors stand for the vector of variables determining disapproved courtship practices among the respondents. $\beta_{0}$ is the constant; $\beta_{\mathrm{n}}$ is the vector of parameters of all the independent variables in the model; $\mu$ is the error term capturing the effects of other factors not included in the model; and $i$ is the cross-sectional unit of the data.

Equation (2) is the model for the effects of disapproved courtship practices:

$$
\log \left[\frac{\operatorname{Pr}(\text { Effofdisapprovedcouship }}{1-\operatorname{Pr}(\text { Effofdisapprovedcouiship }}\right]_{i}=\beta_{0}+\beta_{n} \text { Factors }_{i}+\mu_{i}-------------(2)
$$

Where $\operatorname{Pr}$ (Effofdisapprovedcourtship) is the probability of recording negative outcomes of disapproved courtship practices; 1$\operatorname{Pr}$ (Effofdisapprovedcourtship) is the probability of not recording negative outcomes of disapproved courtship practices; and Factors stand for the vector of variables determining negative outcomes of disapproved courtship practices among the respondents. The remaining variables remain as defined under equation (1).

From the qualitative approach, the study applied an exegetical and descriptive methodologies. This is in view of the necessity to analytically interpret the data obtained from library sources and researchers' observation on happenings in the modern context to solve the problem of the study area. 


\section{ISLAMIC PRINCIPLES ON KHIT⿱BAH AND COURTSHIP}

The terms khitbah and courtship are often used interchangeably by some scholars, ${ }^{19}$ while others use them differently. For a group, this is simply because the terms connote different things, though, may have some overlapping tendencies as clarified above. Whereas, for another group, khitbah is considered permissible while courtship is understood to be impermissible in Islam which is counted as one of the violations in khitbah that prospective couple should not go into. ${ }^{20}$ However, considering the realities of the modern world, where Young Muslim intending couples court the 'western' way, this research deems it necessary to uncover those Shariah regulations that if heeded to, would sanitize courtship and make it permissible in the name of "Islamic/Shariahcompliant courtship"; but if contravened the provisions of the Shariah, would be labelled "un-Islamic courtship". This is because, the Shariah has allowed for healthy familiarization and conversation between intending couples as would be explained subsequently in this paper. Against this backdrop, the following Shariah guiding principles should be observed by the intending Muslims couple in khitbah and courtship.

According to the generality of the scholars, engagement (khitbah) is a permissible act (mubāhn). But Dāwud of Dhāhiriyyah opines that it's wājib, ${ }^{21}$ while Shaykh al-'Uthaymin logically inclined to a view that it is a shart (condition), as he mentioned among the conditions of marriage, the consent of the spouses. ${ }^{22}$ The reason behind these divergent views is whether the actions of the Prophet (SAW) will be considered as binding or not binding. As he has unfailingly conducted khitbah in all his marriages. ${ }^{23}$ Likewise, he warned against multiple khitbah on a single lady that:

$$
\text { يأذن لهذب ألخاطب الرجل على خطبة أخيه ، ووفي لفظ: حتى يترك الخاطب قبله أو }
$$

19 M.M. al-Jibali, The Quest for Love and Mercy: Regulations for Marriage and Wedding in Islam (USA: Al-Kitaab and As-Sunnah Publishing, 2005), 35.

20 A.M. Bello, Marriage and Wedding Philosophy in Islam (N.P: Marqais Publishers, 2015), 90.

21 Abī Wālid Muḥammad Ibn Aḥmad Ibn Muḥammad Ibn Aḥmad Ibn Rushd alQurțubī, Bidāyah al-Mujtahid wa al-Nihāyah al-Muqtașid, vol. 3 (Qāhirah: Dār al-Hadìth, 2004), 31.

22 M.S. al-'Uthaymīn, al-Zawāj wa Majmū'ah As 'ilah fì Ahkāmih (Marriage and a Collection of Questions Regarding its Jurisdictions) (KSA, Onaizah: Madar alWatan Publishers, 1432H), 15.

23 Abī Wālid Muḥammad Ibn Aḥmad Ibn Muḥammad Ibn Aḥmad Ibn Rushd alQurțubī, Bidāyah al-Mujtahid wa al-Nihāyah al-Muqtașid, vol. 3, 31. 
"A man should not propose after the proposal of his brother but wait until the first one gives up or permits him to do so." 24

While explaining the maqāṣid al-sharī'ah for legalizing khiṭbah, Sham submits that:

"The legal wisdom behind the permissibility of engagement (khitbah) is to make the other members of the society know that such and such woman is attributed to such and such man. Hence, sending message for asking her hand in marriage (nikāh) by another man is not correct." 25

\section{ETIQUETTES OF KHIṬAH AND COURTSHIP}

\section{Looking at the Prospective Spouse}

Looking at the prospective spouse as much as normally possible to a permissible degree covering the privacy ( 'awrah) that would please and fascinate the other side is allowed in Islam. This could be discerned from these ahädith of the Prophet (SAW) that:

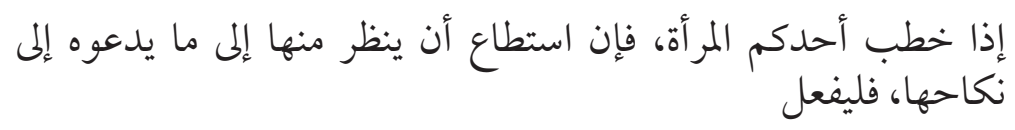

"If one of you proposes to a woman and if he is able to look at a part of her that motivates him to marry her, let him do so" 26 and "When it comes into a person's heart to court a woman, it is permissible for him to look at her." (Recorded by Abu Dawud and Imam Ahmad).

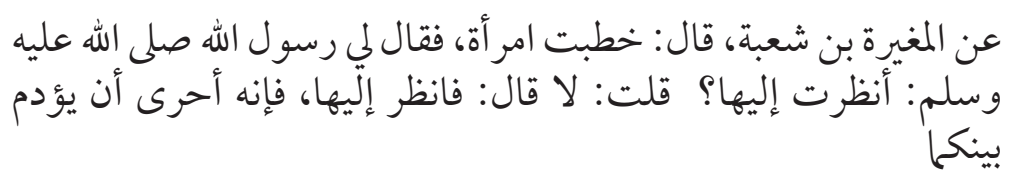

\footnotetext{
24 Muslim bin Hajjāj, Șaḥ̄ḥ Muslim (Bayrūt: Dār Iḥyā’ al-Turāth al-'Arabī, n.d.), book 10, no. hädith 3618.

25 S. Iqbal Shahzad, Some Aspects of Marriage and Divorce in Muslim Family Law, 13.

26 Imām Abū Dāwud and Aḥmad, classed as șahīh by Shaykh Albanī in Ahāaīth alȘahịhah, no. 99.
} 
When al-Mughirah ibn Shu'bah got engaged to a woman, the Prophet (SAW) said to him: "Go look at her, for it is more likely to create affection and consent between you" 27

However, unlike men, a woman's looking should reflect a certain level of modesty and reservation that are characteristics of her femininity. ${ }^{28}$

\section{Performing Istikhārah}

The prophet $(\mathrm{PBUH})$ recommends that whenever a Muslim sets to carry out a permissible thing whatever its nature is, he should perform two units of voluntary șalat (näfilah) and supplicates with the $d u$ 'a of istikhärah. ${ }^{29}$ Therefore, after making all humanly possible efforts in decition making, it is recommended for those who want to marry as part of the etiquettes in choosing their partners to seek Allah's guidance to be able to make the right choice. On this, Allah (SWT) says:

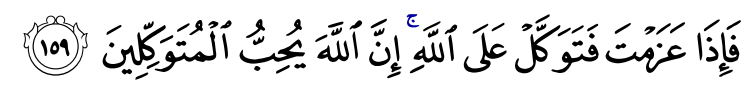

"Then when you have taken a decision, put your trust in Allāh, certainly, Allāh loves those who put their trust (in Him).'

(Surah Āli-'Imrān, 3: 159)

\section{Seeking Spouse's Consent}

Islam gives a right of choice to a virgin woman; it is not valid for her wali to compel her to marry some body she does not like, she rather has the absolute right to choose her life partner, wali shall only guide her to make a right choice. ${ }^{30}$ This is based on the hạdīth reported by 'Abd Allāh Ibn 'Abbās RA that the Prophet (SAW) said:

27 M.I. Tirmidhī, Sunan al-Tirmidhī, vol. 2, ed. Bashar 'Awwad Ma'rūf (Bayrūt: Dār al-Gharb al-Islāmī, 1998), 388. Al-Tirmidhī says it is ḥādīth hassan.

28 S.A. Sha 'ban al-Mișrī, Risālah ila al-Arusaynī wa Fatawāal-Zawāj wa Mu 'āsharah al-Nisā', $1^{\text {st }}$ ed. (Qāhirah: Dār al-Athār, 2010), 62; B.A. Badran, Aḥkām al-Zawāj wa al-Ṭalāq fì al-Islām, Bahthun Tahlīlī wa Dirāsah Muqāranah, $2^{\text {nd }}$ ed. (Mișr: Mațba'ah Dār al-Ta'lif, 1961), 21; M.M. al-Jibali, The Quest for Love and Mercy: Regulations for Marriage and Wedding in Islam, 41.

29 A. Hanbal, Musnad, ed. Shuayb al-Arna'ut, 'Adil Murshid 1st ed. vol. 23 (Lubnān: Mu'assasat al-Risālah, 2001), 55.

30 A.J. al-Jazā'irī, Minhāaj al-Muslim, vol. 2 (Riyāẹ: Dār al-Salām, 2001), 322; M.M. al-Jibali, The Quest for Love and Mercy: Regulations for Marriage and Wedding in Islam, 59. 


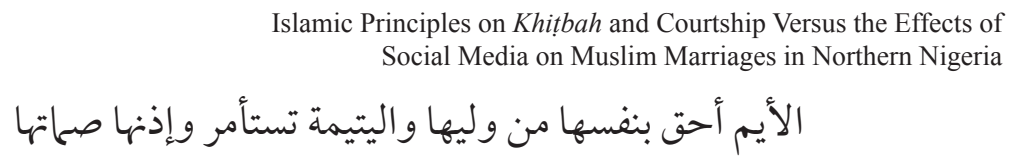

"A woman who has been previously married has more right over herself than her guardian, and a virgin must be asked for her consent, and her silence is her consent." 31

\section{Seeking Advice}

In addition to istikhārah, it is recommended to consult with some knowledgeable people before making an important decision in life such as marriage. Thus, it is recommended for the man and woman or her wali to investigate about his or her intended partner, making sure that she or he has the required good attributes. $^{32}$ That is why a legal guardian to a lady is empowered to check the would-be groom's righteousness and good manners. ${ }^{33}$ Therefore, when the khitbah of a man is approved, it should not be broken except with a valid and cogent reason, al-Jibaly explained that:

"Even though an approved khitbah is not legally binding upon the two involved parties, it still constitutes a mutual pledge for marriage; and breaking it without a valid reason would be an immoral act of dishonesty.. ", 34

\section{Reasonable Khitbah Period}

In view of the fact that, khitbah is a preliminary step towards marriage, scholars emphasize that it is not permitted for the parties to become engaged unless they are free to marry immediately and without impediment. ${ }^{35}$ However, in most cases today, due to one reason or another, marriage contract used to take some longer time after betrothal of the prospective couple, though, long period of

31 Mālik Ibn Ānas, al-Muwațtā ' (Norwich: Diwan Press Ltd., 2014), Book 28, hāàìth no. 2824.

32 A. Najla'a bint Hamad bin 'Alī, 'al-Manhaj al-Nabawī fĩ Muqābalah al-Khātị, Jam'ūn wa Dirāsah wa Takhrij,' al-Adal Journal, vol. 39 (1429H): 64.

33 M.M. Al-Istanbuli, 'The Bride's Boon (Tuhfat Al-'Arous),' trans. AbdelHamid Eliwa, http://www.islambasics.com, 10 ${ }^{\text {th }}$ May, 2019.

34 M.M. al-Jibali, The Quest for Love and Mercy: Regulations for Marriage and Wedding in Islam, 35.

35 E.D. Sudqi, 'The Marriage Contract in the Shari'ah and in the Ahwal Shakhsiyyah Laws of Egypt and Morocco: A Comparative Study,' (Ph.D Thesis, Department of Arabic and Islamic Studies, Faculty of Arts, University of Glasgow, 1990), 38. 
relationship between man and woman is usually discouraged by the Shariah. ${ }^{36}$ Therefore, whether the period taken to familiarize and discover more about one another by the prospective couple is short or long, they should be mindful of the modern challenges posed by globalization that breach some Shariah regulations on courtship.

\section{Interaction and Conversation between an Engaged Couple}

The Shariah allows the potential couple to meet and converse on important issues that will guide their decisions to contract marriage. Yet, this is not without regulations. The venue of the meeting should not be a secluded area and a lady's mahram (non-marriageable relative) or preferably her wali should be present to witness what is going on. The Prophet (SAW) said:

$$
\text { لا يخلون رجل بامر أة إلا و معها ذو محرم }
$$

"No man should be in privacy with a woman except when there is a mahram with her." ${ }^{37}$

$$
\text { لا يخلون أحدكم بامر أة، فإن الشيطان ثالثها }
$$

"A man and a woman cannot be together alone except that shaytan is the third party." 38

This would help to curtail any chance for vain talk, touching, hugging, kissing and other acts of intimacy that may lead to zina which Allah (SWT) has prohibited:

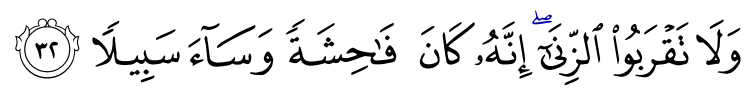

"And come not near to the unlawful sexual intercourse."

(Surah al-Isrā', 17: 32)

Moreover, the Prophet (SAW) said:

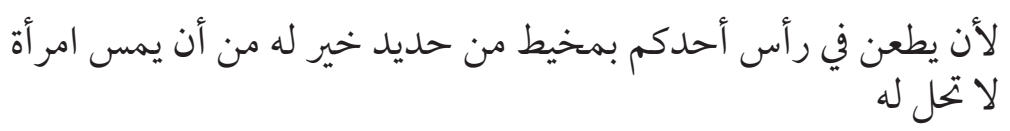

36 M.S. al-'Uthaymīn, al-Zawāj wa Majmū' 'ah As 'ilah fì Ahkāmih, 18.

37 Al-Bukhārī, Ab̄̄ 'Abd Allāh Muhammad Ibn Ismā'il al-Bukhārī al-Ju'fī, Șaḥịh al-Bukhārī, vol. 3 (Riyāḍ: Darussalam, 1997), book 29, hạdīth 85; Muslim bin Hajjāj, Sahīh Muslim, Book 7, no. hāāìth 3110.

38 Imam Aḥmad and Tirmidhī, classed as șaḥ̄ḥ by Shaykh Albanī in Șaḥ̄ḥ al-Jāmi", 2546; A. Hanbal, Musnad, vol. 23; M.I. Tirmidhī, Sunan al-Tirmidhī, vol. 2, 465. 
"For one of you to have his head pierced with an iron needle is better for him than to touch a woman who is not permissible for him (to touch)." 39

It is equally important for the would-be couple to be truthful to one another and shun any iota of deceit and to treat all issues discussed between them as confidential as possible. Because, the seeds of trust and honesty sown during courtship would be reaped during the matrimonial life, which would ultimately lead them to Jannah as the Prophet (SAW) said:

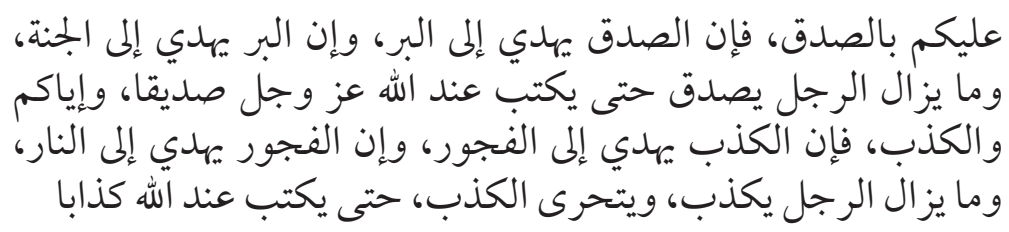

"Truthfulness leads to righteousness, and righteousness leads to Paradise. And a man keeps on telling the truth until he becomes a truthful person. Falsehood leads to al-Fujūr (i.e. wickedness, evil-doing), and al-Fujür (wickedness) leads to the (Hell) Fire, and a man may keep on telling lies till he is written before Allah, a liar." 40

\section{Phone and Social Media Courtship}

All Shariah restrictions to be respected by potential couple in physical interaction during courtship are to be observed over phone calls or social media chat. However, Young Muslim prospective couple grossly abuse these blessings, all in the name of 'one another's discovery'. On this, Dogarawa submits that:

"It must always be remembered that until they are married, they are like any other unrelated men and women to each other and their actions must reflect that fact. Accordingly, the idea of engaging in endless free phone calls, indecent telephone conversations, horrible and immoral text messaging, internet

39 Imām al-Ṭabarānī, al-Mu 'jam al-Kabīr (Qāhirah: Maktabah Ibn Taymiyyah,

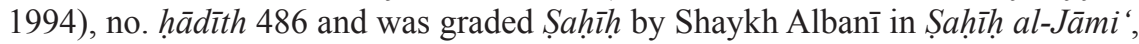
5045.

40 Abī 'Abd Allāh Muḥammad Ibn Ismā'il al-Bukhārī al-Ju'fì̀, Ṣaḥịh al-Bukhārī, vol. 8, book 73, hāaìth 116 . 
chats, exchange of phonographic messages between "fiancées" are not acceptable in Islam." 41

\section{PRESENTATION AND ANALYSIS OF RESULTS}

The above sections provided impetus on the normative ethical standards for Shariah-compliant khitbah and courtship practices. This section therefore, showcases the level of compliance or otherwise by the targeted population to the provisions discussed ubi supra. The results retrieved from the questionnaires are hereunder graphically presented using charts and tables followed by analysis based on some specific variables of the research.

\section{Fig. 1: Graphical Presentation of Gender Distribution of the} Respondents

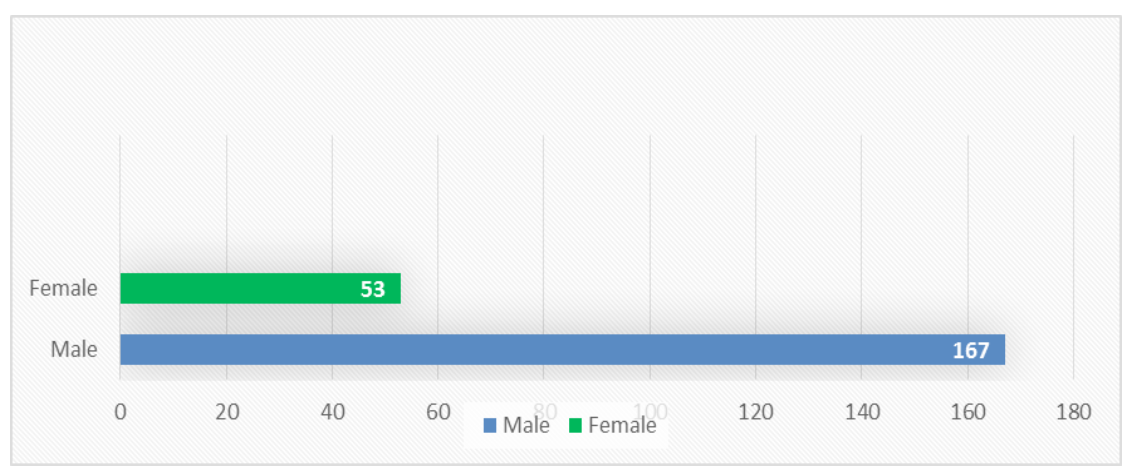

Source: Data generated by authors through questionnaire

As shown in the above chart, out of the 241 persons who responded to the questionnaire, a total of 220 indicated their gender. Males, who constitute the majority, form $76 \%$, where females represent $24 \%$ of the respondents respectively.

${ }_{41}$ A.B. Dogarawa, 'Marriage and Divorce in Islam,' https://mpra.ub.unimuenchen. de/23194/MPRA Paper No. 23194, accessed on 18 August 2018. 


\section{Fig. 2: Graphical Presentation of Age Distribution of the Respondents}

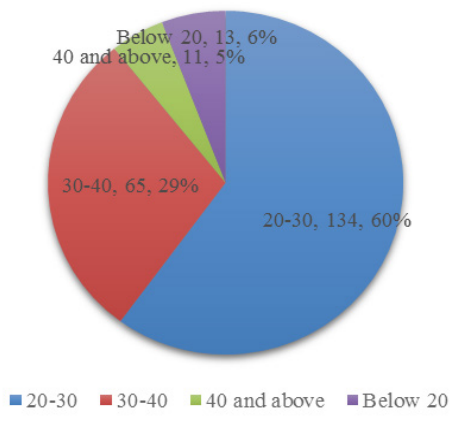

Source: Data generated by authors through questionnaire

This chart shows the age distribution of the respondents where, those below the age of 20 but not less than 15 constitute $6 \%$, those within the range of 20-30 years constitute $60 \%$, those between 30-40 years constitute $29 \%$, whereas, those above 40 years, though, not within the youthful age predefined by this research, constitute $5 \%$. Therefore, out of the 241 respondents, only 223 revealed their age, from which, 212 are significantly within the age group determined as youth in this study. Most significantly also, are those that fall within age brackets of 20-30 years, as the prime targets, who also represent the bulk of the respondents.

Fig. 3: Graphical Presentation of Some Un-Islamic Practices during Courtship

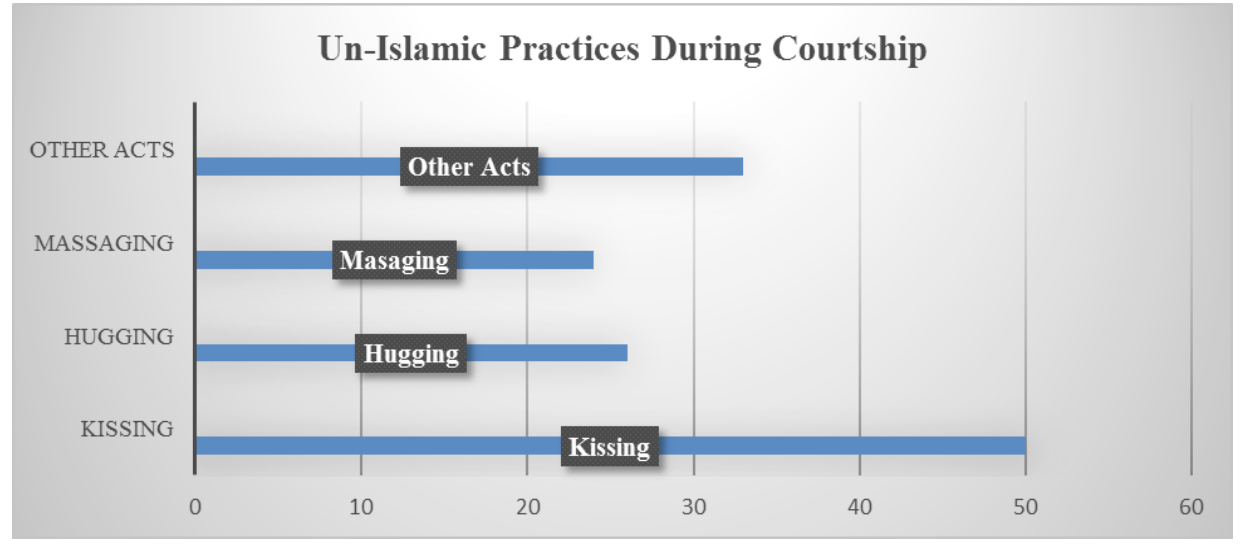

Source: Data generated by authors through questionnaire 
The above chart, captured some of the un-Islamic practices engaged in during courtship as revealed by 133 of the respondents. 50 of them, making $38 \%$ acknowledged that they used to engage in kissing, where 24 respondents, constituting $18 \%$ revealed that they do massage one another, during their physical meetings. In addition, 26 respondents, representing 20\% mentioned that they used to hug one another while 33 respondents equaling $25 \%$ confirmed to be practicing one form of intimacy or the other such as touching hands, sitting waist by waist or on one another's lap.

Table 1: Probit Regression on Factors Determining Disapproved Courtship Practice in Nigeria

\begin{tabular}{lccccc}
\hline \multicolumn{1}{c}{ Variables } & Coefficient & $\begin{array}{c}\text { Marginal } \\
\text { Effect }\end{array}$ & $\begin{array}{c}\text { Standard } \\
\text { Error }\end{array}$ & $\mathbf{Z}$ & $\mathbf{P}>|\mathbf{z}|$ \\
\hline Age-Range & -1.534107 & -.0566625 & .6618439 & -2.32 & 0.020 \\
Educational Level & .6651814 & .032136 & .3190565 & 2.08 & 0.037 \\
Marital Status & 1.253436 & .0579289 & .9452275 & 1.33 & 0.185 \\
& & & & & \\
Having Idea on & -.4936137 & -.0276901 & .5250608 & -0.94 & 0.347 \\
Islamic teachings & & & & & \\
& & & & & \\
WhatsApp & 1.088029 & .1077836 & .483795 & 2.25 & 0.025 \\
Other Social Media & -.2300002 & -.0000312 & .6709844 & -0.34 & 0.732 \\
North-Central & -2.741992 & -.9983256 & .5356516 & -5.12 & 0.000 \\
North-East & -3.2347 & -.900191 & .4554138 & -7.10 & 0.000 \\
North-West & -2.340205 & -.9959805 & .7589691 & -3.08 & 0.002 \\
Constant & 4.241942 & & 1.077162 & 3.94 & 0.000 \\
Prob > chi2 & 0.0000 & & & & \\
Pseudo R2 & 0.3447 & & & & \\
\hline
\end{tabular}

Source: Authors' Computation Using Stata 14.

Table 1 shows that as the age of people increases, the probability of committing disapproved courtship practices decreases by $5.6 \%$ point whereas, increase in modern educational level leads to rise in the chances of engaging in disapproved courtship practices by $3.2 \%$ point. Being married, makes it more likely to engage in disapproved courtship practices by $5.8 \%$ point than being single. Similarly, being aware of Islamic teachings on the conduct of courtship reduces the possibility of committing disapproved courtship practices by $2.8 \%$ point than otherwise. Using WhatsApp as the medium of 
courtship conversation raises the tendency to commit disapproved courtship practices by $10.8 \%$ point than using Facebook. However, using other social media platforms makes it less likely for one to engage in disapproved courtship practices than Facebook by $0.003 \%$ point. Being from NC, NE and NW, makes it less probable to engage in disapproved courtship practices than being from other parts of Nigeria by $99.8,90.0$ and $99.5 \%$ points respectively.

Although, some of the explanatory variables are individually statistically insignificant at either 1,5 or $10 \%$ levels of significance; the variables are collectively significant at all levels of significance because, the Pro $>$ Chi2 $(0.0000)$ is less than the levels of significance $(0.01,0.05$ and 0.10$)$. Again, Pseudo- $\mathrm{R}^{2}$ shows that the independent variables explain only $34.5 \%$ changes in the dependent variable.

Table 2: Probit Model on the Link between Courtship Practice and its Consequences in Nigeria

\begin{tabular}{lccccc}
\hline \multicolumn{1}{c}{ Variables } & Coef. & $\begin{array}{c}\text { Marginal } \\
\text { Effect }\end{array}$ & $\begin{array}{c}\text { Robust } \\
\text { Std. Err. }\end{array}$ & $\mathbf{Z}$ & $\mathbf{P}>|\mathbf{z}|$ \\
\hline $\begin{array}{l}\text { Getting intimate } \\
\text { during courtship }\end{array}$ & .0300489 & .0108477 & .2435828 & 0.12 & 0.902 \\
$\begin{array}{l}\text { Islamically approved } \\
\text { courting }\end{array}$ & -.2693795 & -.0960459 & .2312289 & -1.16 & 0.244 \\
WhatsApp & .4974906 & .1859542 & .2393331 & 2.08 & 0.038 \\
Constant & -.2127728 & & .2638349 & -0.81 & 0.420 \\
Prob $>$ chi2 & 0.0073 & & & & \\
\hline
\end{tabular}

Source: Authors' Computation Using Stata 14

Table 2 reveals that, the probability of recording negative effects of disapproved courtship practices increases by $1.1 \%$ point as prospective couple get intimate during courtship. In the same token, it is also reported in the table that Islamically approved courting reduces the chances of negative effects of disapproved courtship practices by $9.6 \%$ point. However, using WhatsApp as a medium of courting increases the possibility of resulting in negative consequences of disapproved courtship practices by $18.6 \%$ point than using Facebook. The results also suggest that the independent variables are collectively statistically significant in determining the negative effects of disapproved courtship practices albeit some variables in the model are insignificant at individual level. They are collectively significant at all levels of significance given that Prob $>$ Chi2 (0.0073) is less than the levels of significance $(0.01,0.05$ and 0.1$)$. 


\section{DISCUSSION OF RESULTS}

Going by the above analysis, it is pertinent to cleanse the marriage institution from all unlawful and filthy practices at all levels. This is due to the fact that; it is one of the most viable socio-moral institutions through which legitimate human procreation is only possible. Therefore, any lapse in the establishment of such an institution will manifestly affect the whole society. Youth, who are the backbone of every earthly society are supposed to be the vanguards to champion the cause, instead, a considerable number of them turn to be knowingly or otherwise, agents of its destruction in the contemporary time.

Considering the result showing the decrease in probability to committing unlawful practices by the increase in age of the youth, insinuates the tendency of increase in high sense of morality due to maturity. The same result also signifies the fragility of the youthful stage of human development in which the sensual organs and their drives are fully ripen. In order to ensure the incorruptibility, modesty and chastity of the youth, the Prophet (SAW) encourages those who have $b a$ 'ah (i.e. ability) to get married. ${ }^{42}$

Likewise, the result shows that, the tendency to indulge in disapproved courtship behavior is tied up with increase in modern formal educational level. This could be explained by the fact that, since many of the formal institutions of learning in Nigeria are 'western-oriented' with little sense of morality and decency coupled with misapplied freedom of interaction between the opposite sexes. This unhealthy environment gives room for unwarranted exposure to some who passed through the system, though, it largely depends on an individual as may be influenced by a variety of factors. However, this problem could be checked by applying another outcome of this research that with knowledge and practice of the Islamic guidelines on courting, the chances for engaging in disapproved/unlawful courtship practices decrease significantly. As such, the Islamic regulations on marriage generally are effectual right from the choice of the other partner called the "better half". In this regard, Allah (SWT) says in al-Qur'àn:

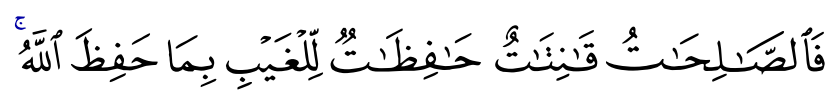

"Therefore the righteous women are devoutly obedient (to Allāh and to their husbands), and guard in the husband's absence what Allāh orders them to guard (e.g. their chastity, their husband's property, etc.)."

${ }_{42}$ Al-Bukhārī, Abī 'Abd Allāh Muḥammad Ibn Ismā'il al-Bukhārī al-Ju'fī, Șahīh alBukhārī, vol. 3, book 62, hāadìth 4. 
In the same vein, the Prophet (SAW) advice men to choose the righteous women for marriage (al-mar'ah al-șälihah) who may or may not have other merits considered by men such as wealth, family status and beauty as mentioned by the Prophet in a $h \bar{a} d \bar{\imath} t h .^{43}$

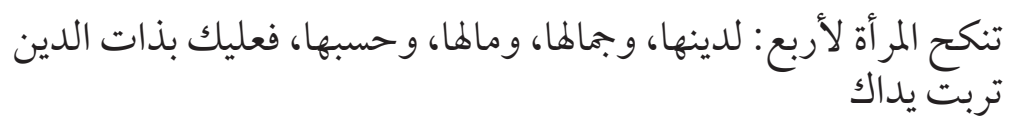

As for ladies, in addition to men having the $b a$ 'ah, they are equally admonished to prioritize for virtue when choosing for husbands, the Prophet (SAW) urged their parents/guardians thus:

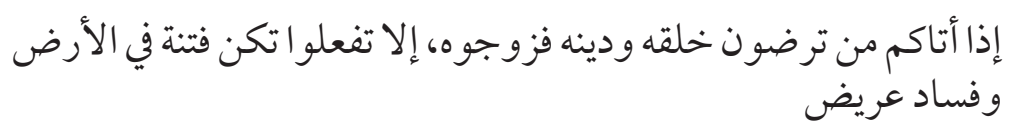

"If there comes to you one with whose religion and attitude you are satisfied, then give your daughter to him in marriage, for if you do not do so, fitnah and mischief will become widespread on earth." ${ }_{44}$

Another aspect of the Islamic regulations on the preliminaries of marriage which is usually neglected in modern time is khitbah (betrothal, proposal or affiancing). Observably, the Islamic ethics of marriage proposal is not normally respected by many families from both sides, resulting to serious violations during courtship such as multiple khitbah which is an order of the day, though, prohibited by the Prophet (SAW). ${ }^{45}$ Contemporarily, it is observed that many young Muslim men in Northern Nigeria go into relationships with ladies without the knowledge or consent of their parents/guardians, a habit that leads to various problems such as unwanted pre or extra-marital affairs, some reported while many were not, especially in courts. ${ }^{46}$ Therefore, based on the above divine recommendations, when considering marriage proposals offered to their wards, parents/guardians should consider all components of materialism as immaterial and monitor closely their children's behavioral

43 Al-Bukhārī, A bī 'Abd Allāh Muḥammad Ibn Ismā'il al-Bukhārī al-Ju'fì̀, Șaḥịh alBukhārī, vol. 3, book 62, hädīth 27.

44 Ibn Mājah Ab̄̄ 'Abd Allāh Muḥammad Ibn Yazid al-Qazwayn̄i, Sunan Ibn Mājah, vol. 1 (Riyāḍ: Dār al-Salām, 2007), 632.

45 M.N. al-Albanī, Irwa' al-Ghalīl (Bayrūt: al-Maktab al-Islāmī, 1985), hạdīth no. 1817.

46 A.U Garba (40) (former Registrar, Doma Area Court, Gombe), in interview with author on 10 November 2017. 
conducts during courtship. Equally, the courtship period should be made as brief as reasonably possible to eliminate chances of illicit relationship, even though, we have not come across any textual evidence specifying the length of courting period. Because, long period of courtship gives room for unnecessary familiarity which usually breaks the usual premarital barriers between the intending couple.

Previously, the commonest traditional conduct of courtship among prospective Muslim couples used to be by physical meeting at the lady's house, chatting in an open space and in the company of her relative. However, with the introduction of mobile phone technology and the recent boom in the telecommunication media, coupled with a blind-folded wholesome imitation of whatever is deemed 'western' in the name of civilization, many people are lured into euphoria of appearing as 'civilized' and act accordingly. With these, courtship becomes adulterated with unworthy behaviors and promiscuous practices in the guise of 'display of true love'. Despite Islam's approval of physical meeting to look up one's propose ${ }^{47}$ seclusion and any act of intimacy tempting to arouse lustful feelings are vehemently prohibited going by the provision of this verse:

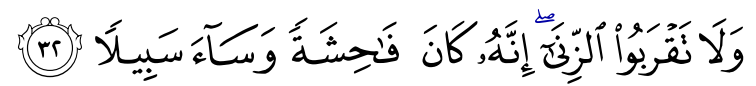

"And come not near to the unlawful sexual intercourse. Verily, it is a Fāhishah [i.e. anything that transgresses its limits (a great sin)], and an evil way (that leads one to Hell unless Allāh forgives him)."

(Surah al-Isrā', 17: 32)

Similarly, the persons concerned must lower their gaze at each other to block the means to lustful looking, Allah (SWT) says:

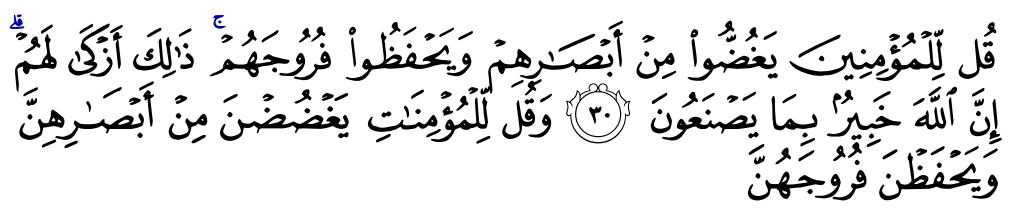

"Tell the believing men to lower their gaze (from looking at forbidden things), and protect their private parts (from illegal sexual acts, etc.). That is purer for them. Verily, Allāh is All-Aware

47 M.N. al-Alban̄i, Irwa' al-Ghalīl, hādīth no. 1791; M.N. al-Albanī, Silsilah alAhâadīth al-Ṣahīhạah (Riyāḍ: Maktabah al-Ma'ārif, 1420), ḥādìth no. 97. 
of what they do. And tell the believing women to lower their gaze (from looking at forbidden things), and protect their private parts (from illegal sexual acts, etc.)..."

(Surah al-Nūr, 24: 30-31)

Unfortunately, trespassing the aforementioned limits in the $21^{\text {st }}$ century permissive moral climate, legalizes kissing, hugging, massaging and host of other supposed conjugal practices among many intending Muslim couples in the area under study. Factors such as satanic temptation, watching local and foreign movies, novels ${ }^{48}$ and bad peer groups are the key identified inspirational mechanisms for disapproved courtship practices among Muslim Youth in northern Nigeria.

While applauding on one hand, the promising facilitation brought by mass media generally in the information and communication industry, health, education and banking sectors as well as in personal and interpersonal affairs, which qualify it to serve as a blessing to the Ummah; however, regrettably, it turns to be a curse to many. As shown by the result of this research, mobile phone and social media courtship beget facility in communication. Yet, based on our observation, unknown to most parents, their wards are lured into erotic conversations/relationships via phone call majorly, using the CUG (Close User Group) platform. This service was meant originally to facilitate communication among men of Nigeria Police Force popularly called "forcecom" introduced by Glo and later by other mobile network providers. This avenue is cheaply being abused by many young prospective Muslim couples because of the "talkmore-charge-less" friendliness of the service. More dangerously however, the risk of illicit relationship increases dramatically when courting through WhatsApp. Among all social networks, as indicated by the result above, WhatsApp appeared to be the most subscribed to by the people and patronized more by the youth. This could not be unconnected from the easy-going and user-friendly nature of the platform enabling chatters to privately converse and discretely share pictures/videos of any kind and make audio or video calls. Therefore, in most cases, we discern, the seeds of physical intimacy are sown through prolong night or secluded calls and chats between the courting parties. Unfortunately, these unethical practices force many youths to resort to masturbation, or at worst, homosexuality, despite their short- and long-term health implications in addition to been religiously reprehensible, blemish and prohibited as indicated in:

48 M. Wabili and Khadijah (Lecturer, Gombe State University), in interview with author via online on 19 October 2017. 


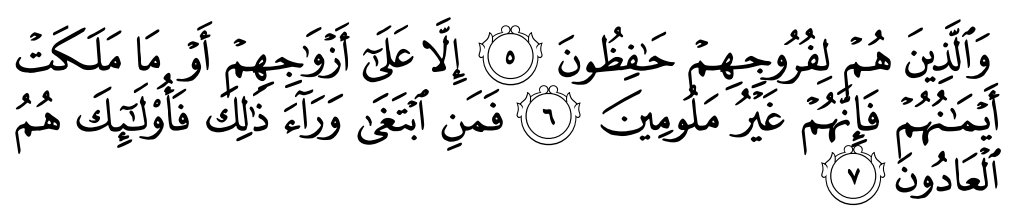

"And those who guard their chastity (i.e. private parts, from illegal sexual acts). Except from their wives or (the captives and slaves) that their right hands possess, for then, they are free from blame. Whoever seeks beyond that, then those are the transgressors."

(Surah al-Mu'minūn, 23: 5-7)

The analysis of results from the second table evidently discerned the marginal effects of ill-modern courtship on the socio-moral standing of Muslim homes and invariably the larger society. The negative effects such as mutual mistrust and incessant rancor are as a result of either ignorance, malpractice or non-practice of the Islamic teachings on what constitute marriage. In addition to the socio-moral consequences of bad courtship mentioned above, it may also serve as a causative factor for seizure of Allah's blessing on the marriage, ${ }^{49}$ or source of Allah's punishment on the couple, ${ }^{50}$ economic hardship and social insecurity are other sides of it. The perpetration of all sorts of atrocities (fasaad) in khitbah, courtship, wedding and ceremonies etc. in deliberate disobedience to Allah and His Messenger, could also be contributing factors to challenges that confront the society. This is an area that needs to be empirically studied. In His Majesty, Allah (SWT) promises to make culprits taste the evils of their handiworks in order for them to repent, a narrative that might also be applicable to the situation under study. This is made clear in the following verses:

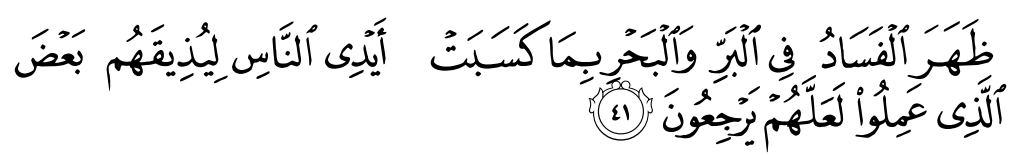

"Evil (sins and disobedience of Allāh, etc.) has appeared on land and sea because of what the hands of men have earned (by oppression and evil deeds, etc.), that Allāh may make them taste a part of that which they have done, in order that they may return (by repenting to Allāh, and begging His Pardon."

(Surah al-Rūm, 30: 41)

\footnotetext{
49 M.M. al-Jibali, The Quest for Love and Mercy: Regulations for Marriage and Wedding in Islam, 95.

50 A.O Kilani (Professor, Islamic Studies, University of Port Harcourt), in interview with author via online on 1 December 2017.
} 
In another verse, Allah (SWT) mentions some repercussions that will befall those who disobey the commands of the Prophet (SAW) that:

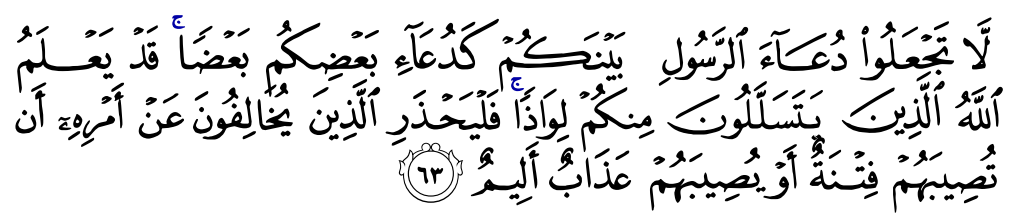

"And let those who oppose the Messenger's (Muhammad SAW) commandment (i.e. his Sunnah legal ways, orders, acts of worship, statements, etc.) beware, lest some fitnah (disbelief, trials, afflictions, earthquakes, killing, overpowered by a tyrant, etc.) befall them or a painful torment be inflicted on them."

(Surah al-Nūr, 24: 63)

Therefore, the fitnah mentioned in this verse, explicates the one referred to in the Prophetic warning cited earlier.

The ultimate way out of all sorts of recessions in Nigeria and elsewhere, be they social, economic, moral or religious, lies in unquestionable compliance to the rules of Shariah by Muslims. To err is human, therefore, in cases of omission or commission against the dictates of the Shariah, people could redress by frequenting istighfar (seeking forgiveness) intending sincere repentance (tawbatan nasuhah) to Allah (SWT) from the evil acts perpetuated. Surely, with Allah (SWT), the door of forgiveness is open to erring servants as explicated in the following verses:

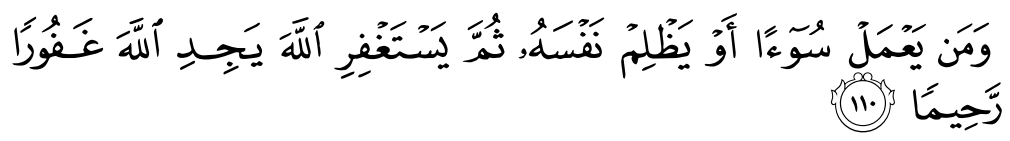

"And whoever does evil or wrongs himself but afterwards seeks Allāh's Forgiveness, he will find Allāh Oft Forgiving, Most Merciful."

(Surah al-Nisā', 4: 110)

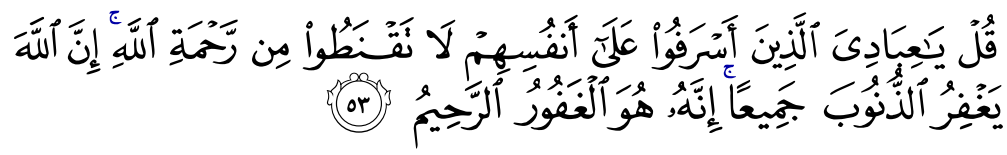

Say: "O 'Ibādi (My slaves) who have transgressed against themselves (by committing evil deeds and sins)! Despair not of 
the Mercy of Allāh, verily Allāh forgives all sins. Truly, He is OftForgiving, Most Merciful."

(Surah al-Zumar, 39: 53)

As reported by Abū Dharr (RA) through Prophet Muhammad (SAW), that Allah (SWT) promised forgiveness to whoever seeks for it in a hāadith alQudsī where He says:

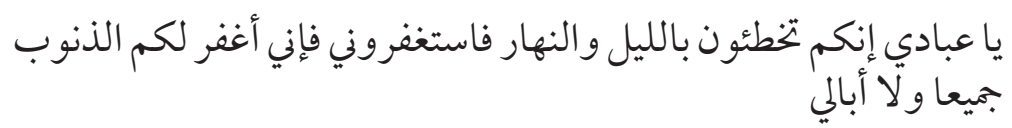

"O My servants, you commit sins by day and by night, and I forgive all sins, so seek forgiveness from Me and I shall forgive you." 51

Some of the fruits of istighfar could be discerned from the following Quranic verse in relation to Prophet Nuh (SAW) and his people which is also applicable to the present generation thus:

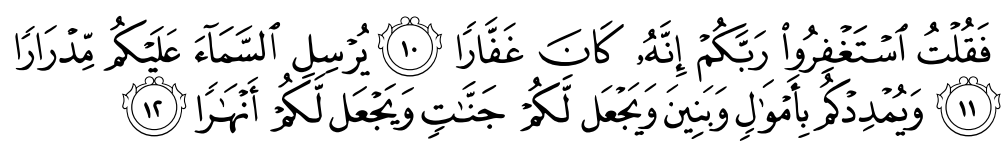

"I said (to them): 'Ask forgiveness from your Lord; Verily, He is Oft-Forgiving; 'He will send rain to you in abundance; 'And give you increase in wealth and children, and bestow on you gardens and bestow on you rivers."

(Surah Nūh, 71: 10-12)

\section{CONCLUSION AND RECOMMENDATIONS}

From the foregoing, it is understood that marriage is the legal union through which human communities are produced. Therefore, what make up marriages in terms of practices given to cultural and religious provisions alongside the moral climate of a certain people, influence greatly, the quality of the institution and the society as a whole. It was established from the results of this study that; a great deal of immodesty saturates the conduct of courtship among young prospective Muslim couples in Nigeria influenced by various agents of globalization such as social media and materialism. The presence of the identified un-Islamic and uncultured practices among youth are linked to many factors such as ignorance of or eschewing Shariah rulings on courtship,

51 Muslim bin Ḥajjāj, Șaḥịh Muslim, book 32, no. hāāìth 6246. 
abuse of agents of globalization and westernization as a result of which varying calamities abound. Based on our findings, the resultant consequences of illmodern courtship, affect not only the couples, but the entirety of the sociomoral and the economic constituents of the matrimonial home and the larger society. Some of these effects include among others, spousal mutual suspicion, mistrust, discord which turns bloody sometimes, and ends in divorce. ${ }^{52}$ Moreover, the upshots do not stop there, but in some instances, impinge on the upbringing of children born out of such type of marriage..$^{53}$ Consequently, the society also becomes affected in many ways. In fact, when a society is so accustomed to immoralities, calamities of varying gravities will ensue ranging from social disorders to economic downturns and insecurity.

Interestingly, when such calamities occur, they depict and signal Allah's reprimands to such a people as divine call to order wherewith sincere repentance and reversion to acts of righteousness, the unpalatable condition will be restored to normalcy. Some Islamic guidelines on courtship were highlighted as steps to help in establishing Shariah-compliant matrimonial homes and societies in the ever challenging $21^{\text {st }}$ century Nigeria in addition to the following recommendations:

a) Youth should fear Allah and guard their utterances and practices while courting and conduct istikhärah before going deep into relationships.

b) Parents should attach premium importance to the noble qualities of virtue and religiosity in addition to possession of $b a$ 'ah while considering marriage proposals of their wards against materialism. They ought to also come to terms with the realities of the $21^{\text {st }}$ century world to be able to fasttrack the conduct of their wards during courtship and ensure compliance to the Islamic rules of khitbah and courtship.

c) Scholars, Muslim organizations and Masajid should restructure and intensify efforts in organizing pre-marital counseling to Muslim youth in secondary schools and tertiary institutions to educate them on making right choices in building families or at best establish formal marriage counseling centers to provide answers to pertinent questions/issues bordering marriage and family to the surrounding Muslim Ummah.

52 M.N. Lemu (Director, Research and Training Department, Da'wah Institute of Nigeria (DIN), Islamic Education Trust (IET), Minna, Niger State), in interview with author via online on 6 December 2017.

53 A.A. Sulaiman (Head of Department, Department of Islamic Studies, Nasarawa State University, Keffi), in interview with author via online on 1 December 2017. 
d) The leadership of the Muslim Ummah in Nigeria should liaise with appropriate government authorities to set up mechanisms for institutionalizing the marriage institution. Judges of Shariah courts should also be empowered and sensitized on the fiqh of marriage and its legal applications and implications to be able to adjudicate on any reported marital issue. A working document ought to also be produced containing rules and regulations on all facets of marriage based on the sources of Shariah. The type initiated by the leadership of the Muslim Ummah in Kano in collaboration with the state government.

e) In order to minimize or curb the menace of immoralities over the cyber space, censorship mechanism ought to be put in place by the Nigerian government to regulate the activities of social networking sites and other internet-based video and picture sharing domains.

Going by the above recommendations, amidst globalization, courtship would be conducted decently, resulting to a modest marriage contract, establishing a morally upright and peaceful matrimony. It is posited that, out of such homes, righteous children will be procreated to make a better modern Muslim society characterized by spiritual commitment, economic prosperity and social cohesion as echoed in the following verse:

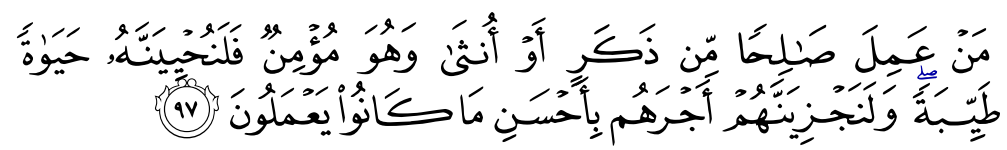

"Whoever works righteousness, whether male or female, while he (or she) is a true believer (of Islamic Monotheism) verily, to him We will give a good life (in this world with respect, contentment and lawful provision), and We shall pay them certainly a reward in proportion to the best of what they used to do (i.e. Paradise in the Hereafter)."

(Surah al-Naḥl, 16: 97)

\section{REFERENCES}

A. Hanbal, Musnad, ed. Shuayb al-Arna'ut, 'Adil Murshid 1 $1^{\text {st }}$ ed. vol. 23 (Lubnān: Mu'assasat al-Risālah, 2001).

A. L. Abubakar, 'Youth Unemployment, Poverty and Political Violence in Nigeria,' in the Proceeding of the Conference on: Youth Unemployment, Poverty and Political Violence in Nigeria (Gombe: Department of Sociology, Gombe State University, 2012). 
A. Najla'a bint Hamad bin 'Alī, 'al-Manhaj al-Nabawī fì Muqābalah al-Khāțib, Jam 'ūn wa Dirāsah wa Takhrij,' al-Adal Journal, vol. 39 (1429H): 42128.

A.A. Rabiu, 'Effects of Electronic Media on the Muslim Youth of Gombe Metropolis,' Journal of Religion and Culture, UniPort. vol. 17/1 (2017): 60-75.

A.B.Dogarawa, 'Marriage and Divorce in Islam,'https://mpra.ub.unimuenchen. de/23194/MPRA Paper No. 23194, accessed on 18 August 2018.

A.J. al-Jazā'irī, Minhāj al-Muslim, vol. 2 (Riyāḍ: Dār al-Salām, 2001).

A.M Bello, Marriage and Wedding Philosophy in Islam (N.P: Marqais Publishers, 2015).

Abī Wālid Muḥammad Ibn Aḥmad Ibn Muḥammad Ibn Aḥmad Ibn Rushd al-Qurțubī, Bidāyah al-Mujtahid wa al-Nihāyah al-Muqtașid, vol. 3 (Qāhirah: Dār al-Hadīth, 2004).

Al-Bukhārī, Abī ‘Abd Allāh Muḥammad Ibn Ismā'il al-Bukhārī al-Ju'fī, Șaḥīh al-Bukhārī, vol. 3 (Riyāẹ: Darussalam, 1997).

B.A. Badran, Ahkām al-Zawāj wa al-Ṭalāq fì al-Islām, Bahthun Tahlīlī wa Dirāsah Muqāranah, 2 ${ }^{\text {nd }}$ ed. (Mișr: Maṭba'ah Dār al-Ta'lif, 1961).

Craig Smith, '65 Amazing WhatsApp Statistics and Facts.' DRM, https:// expandedramblings.com/index.php/whatsapp-statistics/, assessed on 24 January 2018.

E.D. Sudqi, 'The Marriage Contract in the Shari'ah and in the Ahwal Shakhsiyyah Laws of Egypt and Morocco: A Comparative Study,' (Ph.D Thesis, Department of Arabic and Islamic Studies, Faculty of Arts, University of Glasgow, 1990).

I. O. Oloyede, 'An Islamic Perspective of Youth Development,' in African Culture, Modern Science and Religious Thought, ed. P.A. Dopamu (Ilorin: African Centre for Religions and the Sciences, University of Ilorin, 2003), 664-673.

Ibn Mājah Abī 'Abd Allāh Muḥammad Ibn Yazid al-Qazwaynī, Sunan Ibn Mājah, vol. 1 (Riyāḍ: Dār al-Salām, 2007).

Imām al-Ṭabarānī, al-Mu 'jam al-Kab̄̄r (Qāhirah: Maktabah Ibn Taymiyyah, 1994).

M.I. Tirmidhī, Sunan al-Tirmidhī, vol. 2, ed. Bashar 'Awwad Ma'rūf (Bayrūt: Dār al-Gharb al-Islāmī, 1998).

M.M. Al-Istanbuli, 'The Bride's Boon (Tuhfat Al-'Arous),' trans. AbdelHamid Eliwa, http://www.islambasics.com, 10 ${ }^{\text {th }}$ May, 2019. 
M.M. al-Jibali, The Quest for Love and Mercy: Regulations for Marriage and Wedding in Islam (USA: Al-Kitaab and As-Sunnah Publishing, 2005).

M.N. al-Alban̄̄, Irwa' al-Ghalīl (Bayrūt: al-Maktab al-Islāmī, 1985).

M.N. al-Albanī, Silsilah al-Aḥādīth al-Ṣahīhah (Riyāḍ: Maktabah al-Ma'ārif, 1420).

M.S. al-'Uthaymīn, al-Zawāj wa Majmū'ah As'ilah fì Ahkāmih (Marriage and a Collection of Questions Regarding its Jurisdictions) (KSA, Onaizah: Madar al-Watan Publishers, 1432H).

Mālik Ibn Ānas, al-Muwatțā' (Norwich: Diwan Press Ltd. 2014).

Muslim bin Hajjāj, Saḥ̄ḥ Muslim (Bayrūt: Dār Iḥyā’ al-Turāth al-'Arabī, n.d.).

N.a., 'Nigeria's Public Policy and the Youth,' http://www.thetidenewsonline. com, accessed on 6 July 2014.

P.K. Olawale, 'The Moral Teachings of Suratu Luqman as Paradigms for Character Building.,' NATAIS Journal, vol. 6/2 (2002): 13-28.

Peter R. Scott \& J. Mike Jacka, Auditing Social Media: A Governance and Risk Guide (New Jersey: John Wiley \& Sons, Inc. 2011).

S. Iqbal Shahzad, Some Aspects of Marriage and Divorce in Muslim Family Law (n.p.: n.p., n.d.).

S. Sābiq, Fiqh al- Sunnah, vol. 2 (Bayrūt: Dār al-Kutub al-‘Arabī, 1977).

S.A. Sha'ban al-Mișrī, Risālah ila al-Arusaynī wa Fatawā al-Zawāj wa Mu 'āsharah al-Nisā', $1^{\text {st }}$ ed. (Qāhirah: Dār al-Athār, 2010).

T. AbdulKariem, 'Administration of Islamic Law of Marriage and Divorce in South Africa,' (Master Dissertation, Department of Islamic Studies, Faculty of Arts, University of Durban-Westville, 1993).

Wikipedia, 'Modernity,' https://en.wikipedia.org/wiki/Modernity, accessed on 18 December 2017.

Z. I. Oseni, 'Islam and Morality,' Nigeria Studies in Religious Tolerance, vol. 2/26 (1988): 6-11.

\section{Interviews}

A.A. Sulaiman (Head of Department, Department of Islamic Studies, Nasarawa State University, Keffi), in interview with author via online on 1 December 2017.

A.O Kilani (Professor, Islamic Studies, University of Port Harcourt), in interview with author via online on 1 December 2017. 
A.O. Giwa (Masjid Imam, Ogun State), in interview with author via online on 6 December 2017.

A.U Garba (40) (former Registrar, Doma Area Court, Gombe), in interview with author on 10 November 2017.

I. Bello (Senior Researcher, Da'wah Institute of Nigeria (DIN), Islamic Education Trust (IET), Minna, Niger State), in interview with author via online on 12 December 2017.

M. Wabili and Khadijah (Lecturer, Gombe State University), in interview with author via online on 19 October 2017.

M.N Lemu (Director, Research and Training Department, Da'wah Institute of Nigeria (DIN), Islamic Education Trust (IET), Minna, Niger State), in interview with author via online on 6 December 2017.

Y.O Imam (56) (Professor, Islamic Studies, University of Ilorin, Kwara State, Nigeria), in interview with author via online on 3 December 2017. 
Jurnal Syariah, Jil. 27, Bil. 1 (2019) 113-144 